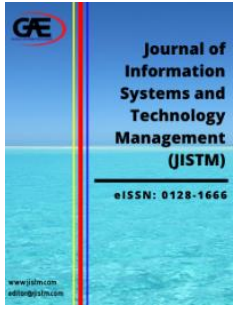

\author{
JOURNAL OF INFORMATION \\ SYSTEM AND TECHNOLOGY \\ MANAGEMENT (JISTM)

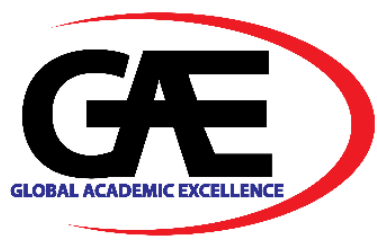

\title{
ENVIRONMENTAL FACTORS PREDICTING MALAYSIAN UNIVERSITY GRADUATES' CYBER ENTREPRENEURIAL INTENTION
}

\author{
Siti Intan Farahindiana Mhd Fauzy ${ }^{1 *}$, Rosmelisa Yusof ${ }^{2}$, Aizzat Mohd Nasurdin $^{3}$
}

1 School of Management, Universiti Sains Malaysia, Malaysia

Email: ctfarira@yahoo.com

2 School of Management, Universiti Sains Malaysia, Malaysia

Email: rosmelisa@usm.my

3 School of Management, Universiti Sains Malaysia, Malaysia

Email: aizzat@usm.my

* Corresponding Author

\section{Article Info:}

Article history:

Received date: 10.10 .2021

Revised date: 15.11.2021

Accepted date: 25.11 .2021

Published date: 01.12.2021

\section{To cite this document:}

Mhd Fauzy, S. I. F., Yusof, R., \& Nasurdin, A. M. (2021). Environmental Factors Predicting Malaysian University Graduates' Cyber Entrepreneurial Intention. Journal of Information System and Technology Management, 6 (24), 334340.

\section{DOI: $10.35631 / J I S T M .624031$}

This work is licensed under CC BY 4.0



Abstract:

The issue of unemployment, particularly among university graduates has been plaguing the world with no clear solution in sight. Despite various government intervention, the unemployment rate continued to rise especially during the COVID-19 period. Cyber entrepreneurship can be one of the ways for graduates to be self-employed. Having said that, the studies pertaining cyber entrepreneurial intention among Malaysian university graduates is not common where the predicting factors are not well justified. Prior research conducted has revealed the significant role of the government support and university support in influencing graduate's intention to venture into entrepreneurship, but there are inconsistencies recorded. In addition, there are limited studies being conducted on the role of entrepreneurial drive in mediating the relationship between environmental factors and cyber entrepreneurial intention. Thus, it calls for further investigation on these issues. This study conducted a survey with a sample of 238 students from selected Malaysia public universities. The findings revealed that government support does not influence the student's cyber entrepreneurial intention while university support did exert significant impact. Besides, entrepreneurial drive only mediates the relationship between university support and cyber entrepreneurial intention.

Keywords:

Cyber Entrepreneurship, Entrepreneurial Intention, Entrepreneurial Drive 


\section{Introduction}

The booming trend of internet usage has transformed the landscape of human's way of living from learning, working, communication and considerably the process of selling and buying things. Concurrently, ever since the implementation of Movement Control Order (MCO), the level of internet consumption recorded a substantial increase compared to before the MCO period (MCMC, 2020). It could be attributed to the restrictions imposed on Malaysian where they are forced to work and sit for classes from the comfort of their home instead of face to face session. Due to the longer hours at home, it is not unusual that the level of internet usage continues to rise. Malaysian Communications and Multimedia Commission (2020) in their survey revealed that almost $90 \%$ of the internet users in Malaysia are most likely will maintain their level of internet usage post pandemic. During MCO, the growth of cyber businesses in Malaysia has been very progressive since most consumer prefer to buy goods online instead of going to the physical store to minimize exposure to Covid-19. This situation opens valuable opportunity for individuals to start their cyber business, especially among graduates who are not yet able to secure a job after their graduation. It can be one of the solutions for graduates to resolve the unemployment issue by being self-employed.

When discussing about unemployment, it is a global issue that does not only impact Malaysia, but the whole world including developed countries. Unemployment can be defined as an individual who are not employed despite wanting to and having the ability to work (Pettinger, 2010). Suraya et al. (2018) postulated that while poor countries are usually synonym with higher unemployment rate, developed countries are no exception. In 2020, Malaysia ranked at $4^{\text {th }}$ place among ASEAN countries with highest unemployment rate at $4.8 \%$. There is an increase of unemployment rate from the previous year at 3.2\% in 2019 (International Monetary Fund, 2020). With the rising number of graduates produced by higher learning institutes in Malaysia each year, the job market is understandably over saturated. Some of the major causes of unemployment in Malaysia were found to be the poor skills and lack of relevant experience (Hanapi \& Nordin, 2014). By taking advantage of the rising trend of cyber awareness, graduates can become self-employed by venturing into cyber entrepreneurship. Entrepreneurship after all, has been proven to be instrumental in helping lessen the unemployment rate (Mohd Hasril, Siti Norain, \& Noorazman, 2017).

Before deciding to venture into entrepreneurship, one needs to have the intention first (Iakovleva, Kolvereid, \& Stephan, 2011). Ajzen (2014) defined entrepreneurial intention as individual's commitment to perform entrepreneurial behaviour. Environmental factors' influence on cyber entrepreneurial intention should not be disregard since entrepreneurship operated in their surroundings and will be affected by the events that is happening around them (Stephen \& Uhlaner, 2010). Among others, government support and university support were found to exhibited strong influence on an individual's cyber entrepreneurial intention (Saeed et al., 2015; Minniti, 2008).

\section{Literature Review}

\section{Government support}

Government support can be defined as individual's perception of the availability of government support in aiding them during their entrepreneurship activities such as capital, taxes exclusion, and guidance (Minniti, 2008). Prakash, Jain, and Chauhan (2015) in their study found that government support exerted substantial impact on individual's entrepreneurial intention. 


\section{University Support}

University is a place to nurture students to become entrepreneurs by providing necessary supports and opportunities, in which it can be the pillar for students who plan to venture into entrepreneurship after their graduations. University support has been noted as one of the push factors that will highly influence students to become entrepreneurs (Saeed et al., 2015).

\section{Entrepreneurial Drive}

Florin et al. (2007) defined entrepreneurial drive as the individual's perception where their likeliness to venture into entrepreneurship will depend on the level of feasibility and desirability of the situation. A study revealed the great influence of entrepreneurial drive in affecting one's entrepreneurial intention (Florin et al., 2007).

\section{Cyber Entrepreneurial Intention}

This study decided to explore the realm of cyber entrepreneurship instead of the traditional entrepreneurship. Cyber entrepreneurial intention is defined as the tendency of an individual to venture into cyber entrepreneurship, in which the buying and selling process were conducted online (Wang et al., 2016). The research on cyber entrepreneurship particularly in Malaysia has been scarce (Badaruddin \& Abdullah, 2018). So, it is timely for the current research to be conducted to explore the factors affecting cyber entrepreneurial intention.

\section{Research Framework}

Figure 1 illustrated the research framework where the independent variables are government support and university support, entrepreneurial drive will be the mediating variable and cyber entrepreneurial intention as the dependant variable. There are 4 hypotheses to be tested and the details are as below:

Hypothesis 1: Government support will be positively related to entrepreneurial drive Hypothesis 2: University support will be positively related to entrepreneurial drive Hypothesis 3: Entrepreneurial drive will mediate the relationship between government support and cyber entrepreneurial intention

Hypothesis 4: Entrepreneurial drive will mediate the relationship between university support and cyber entrepreneurial intention.

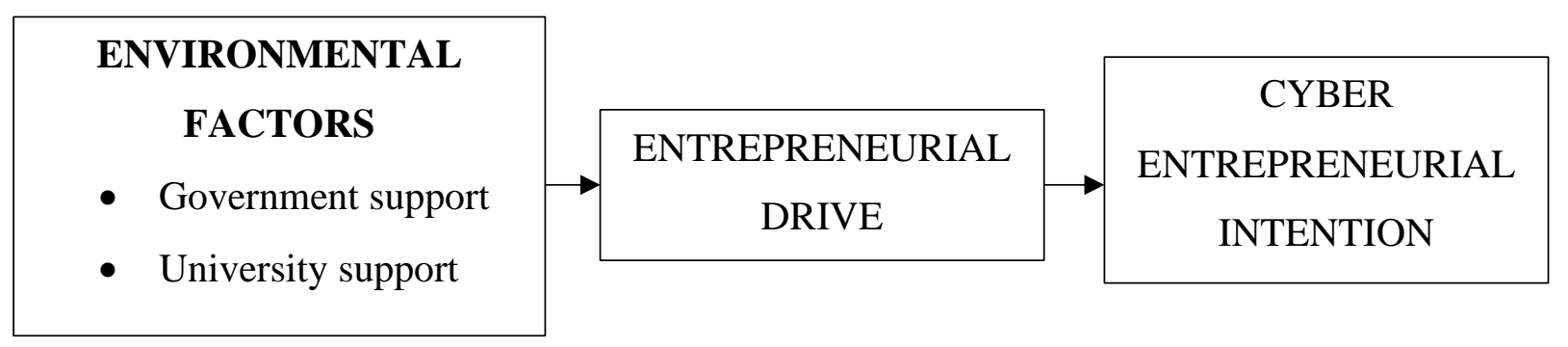

Figure 1: Research Framework 


\section{Methodology}

This study employed a judgmental sampling technique to conduct the quantitative method. The sample was chosen from 238 public university undergraduate students where the inclusion criteria are as follows:

1. The students must enrol in Bachelor of Business Administration (BBA) from selected Malaysian public universities

2. The students must be in their final year of study

The current study uses questionnaire adopted from relevant sources to be given out to the respondents. Government support questions were adopted from Malebana (2014), and university support were adopted from Saeed et al. (2015). On the other hand, the measurement for entrepreneurial drive were adopted from Solesvik et al. (2012) while cyber entrepreneurial intention measurements were taken from Liñán and Chen (2009). The questions are measured using 7 Likert scale where the lowest scale was depicted as '1-strongly disagree' and the highest scale was depicted as '7-strongly agree'. The results obtained were evaluated using SPSS and PLS-SEM.

Before the data collection period, the researcher requested for the permission to conduct research at the respective administrative division of the university. All of them decline the request for face to face meeting and instructed the researcher to provide details of the research through email. After several email exchange, all university allowed the researcher to use their students as the sample, but on one condition. No student's personal information will be provided to protect their privacy. The researcher agreed to the condition and send the link to the questionnaire. The administrative staff then forwarded the link to students that falls within the inclusion criteria.

\section{Findings}

\section{Respondents' Demographic}

More than half of the respondents are female while the rest are male students. In terms of age, students aged 22 recorded the most responses while 26 years old students yielded the least responses. According to the results, Malay accounted for most of the respondents, followed by Chinese and Indian respectively. There are no other races recorded.

\section{Reliability}

The study tested the reliability of the measurements used by looking at the Cronbach's alpha value. In order to prove the reliability, all variables need to obtain values of more than 0.70 (Sekaran \& Bougie, 2010). All variables recorded values of more than 0.70 each. Thus, the reliability of the measurements was proven. Table 1 exhibit the Cronbach's alpha value for the measurements.

Table 1: Reliability Results

\begin{tabular}{cc}
\hline Variables & Cronbach's alpha \\
\hline Government support & 0.83 \\
University support & 0.77 \\
Entrepreneurial drive & 0.96 \\
Cyber entrepreneurial intention & 0.90 \\
\hline
\end{tabular}




\section{Descriptive Analysis}

The mean score for government supports was $6.01(\mathrm{SD}=0.87)$ while university supports was $6.12(\mathrm{SD}=0.96)$. For entrepreneurial drive, the mean was $6.16(\mathrm{SD}=0.90)$. On the other hand, cyber entrepreneurial intention recorded a mean score of $6.09(\mathrm{SD}=0.96)$. Table 2 illustrated the summary of the mean and standard deviation (SD).

Table 2: Descriptive Analysis

\begin{tabular}{lll}
\hline \multicolumn{1}{c}{ Construct } & Mean & SD \\
\hline Government support & 6.01 & 0.87 \\
University support & 6.12 & 0.96 \\
Entrepreneurial drive & 6.16 & 0.90 \\
Cyber entrepreneurial intention & 6.09 & 0.96 \\
\hline
\end{tabular}

\section{Hypotheses Testing And Mediating Effect}

The objective of the research is to investigate the relationship between environmental factors (government support and university support) and cyber entrepreneurial intention. Besides, this study also intends to determine the role of entrepreneurial drive as a mediator. Thus, there are 4 hypotheses tested and the results are shown in Table 3.

H1 illustrate the relationship between government support and entrepreneurial drive. As summarized in Table 3, the relationship was not significant ( $\mathrm{t}$-value $=1.254, \mathrm{p}>0.05$. Thus, this hypothesis was not supported.

$\mathrm{H} 2$ illustrate the relationship between university support and entrepreneurial drive. As summarized in Table 3, the relationship was found to be significant ( $\mathrm{t}$-value $=2.113, \mathrm{p}<0.05$ ). Thus, this hypothesis was supported.

H3 illustrate that entrepreneurial drive mediate the relationship between government support and cyber entrepreneurial intention. As summarized in Table 3, the relationship was not significant ( $t$ value $=1.321, \mathrm{p}>0.05$ ). Thus, this hypothesis was not supported.

$\mathrm{H} 4$ illustrate that entrepreneurial drive mediate the relationship between university support and cyber entrepreneurial intention. As summarized in Table 3, the relationship was found to be significant $(\mathrm{t}$-value $=2.026, \mathrm{p}<0.05)$. Thus, this hypothesis was supported.

Table 3: Result of Hypotheses Testing and Mediating Effect

\begin{tabular}{clccc}
\hline Hypothesis & \multicolumn{1}{c}{ Relationship } & t-test & p-value & Decision \\
\hline $\mathbf{H 1}$ & $\begin{array}{l}\text { Government support will be positively } \\
\text { related to entrepreneurial drive }\end{array}$ & 1.254 & 0.163 & Not supported \\
& $\begin{array}{l}\text { University support will be positively } \\
\text { related to entrepreneurial drive }\end{array}$ & 2.113 & 0.031 & Supported \\
& $\begin{array}{l}\text { Entrepreneurial drive will mediate the } \\
\text { relationship between government } \\
\text { support and cyber entrepreneurial } \\
\text { intention }\end{array}$ & & 0.321 & Not supported \\
& $\begin{array}{l}\text { Entrepreneurial drive will mediate the } \\
\text { relationship between university support } \\
\text { and cyber entrepreneurial intention. }\end{array}$ & & & \\
& & & & \\
\end{tabular}




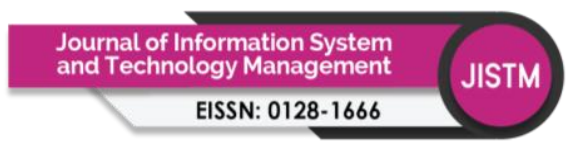

Volume 6 Issue 24 (December 2021) PP. 334-340 DOI: 10.35631/JISTM.624031

\section{Conclusion}

The findings from this study found that government support does not exert significant influence on the students' cyber entrepreneurial intention despite previous study's claim. While university support was found to have significant effect on the students' cyber entrepreneurial intention which is in line with past study. This research is not without limitation. First, the sample were relatively small since they were selected from only a few select public universities in Malaysia. Besides, only students undertaking Bachelor of Business (BBA) were selected as the respondents. Next, there are limited variables being tested. Future researchers should consider choosing sample from a wider pool and includes several other relevant disciplines other than BBA. In addition, prospective research can also investigate more variables including environmental, individual, and cultural to improve the generalizability.

Despite proven to be insignificant, the role of government support on influencing individual's entrepreneurial inclination should not be brush aside. The government and universities as well as related authorities should pay attention to the possible factors that will motivate students to become cyber entrepreneurs to design appropriate mechanism to help propel their cyber entrepreneurial intention.

\section{References}

Ajzen, I. (2014). The theory of planned behaviour is alive and well, and not ready to retire: a commentary on Sniehotta, Presseau, and Araujo-Soares. Health Psychology Review, 9(2), 131-137.

Badaruddin, M. N., \& Abdullah, N. (2018). Study on intention mediating role in cyber entrepreneurship adoption among the undergraduates in Malaysia. International Journal of Advanced Scientific Research and Management, 3(4).

Florin, J., Karri, R., \& Rossiter, N. (2007). Fostering entrepreneurial drive in business education: An attitudinal approach. Journal of Management Education, 31(1), 17-42.

Hanapi, Z. \& Nordin, M. S. (2014). Unemployment among Malaysia graduates: Graduates' attributes, lecturers' competency, and quality of education. Procedia-Social and Behavioral Sciences, 1056-1063.

Iakovleva, T., Kolvereid, L., \& Stephan, U. (2011). Entrepreneurial intentions in developing and developed countries. Education \& Training, 53(5), 353-370.

International Monetary Fund (2019). Retrieved 18 October 2019 from https://www.imf.org/en/Home.

Linan, F., \& Chen, Y. W. (2009). Development and cross-cultural application of a specific instrument to measure entrepreneurial intentions. Entrepreneurship Theory \& Practice, 33(3), 593-617.

Malaysian Communications and Multimedia Commission (2020). Retrieved 20 December 2020, from https://www.mcmc.gov.my/en/home.

Malebana, M. (2014). The effect of knowledge of entrepreneurial support on entrepreneurial intention. Mediterranean Journal of Social Sciences, 5(20), 1020-1028.

Minniti, M. (2008). The role of government policy on entrepreneurial activity: productive, unproductive, or destructive? Entrepreneurship Theory \& Practice, 32(5), 779-790.

Mohd Hasril A., Siti Norain J., \& Noorazman Abd S. (2017). Level of Knowledge, Skill and Ability of Trainees in Electrical Wiring in Technical Entrepreneur Development. Sains Humanika 9(1-5), 109-117.

Pettinger, T. (2010). Definition of Unemployment. Economics. Retrieved from: http://www.economicshelp.org/blog/2247/unemployment/definition-ofunemployment/. 
Volume 6 Issue 24 (December 2021) PP. 334-340 DOI: 10.35631/JISTM.624031

Prakash, D., Jain, S., \& Chauhan, K. (2015). Supportive government policies, locus of control and student's entrepreneurial intensity: A study of India. Journal of Global Entrepreneurship Research, 5(1). https://doi.org/10.1186/s40497-015-0042-7

Saeed, S., Yousafzai, S. Y., Yani-De-Soriano, M., \& Muffatto, M. (2015). The role of perceived university support in the formation of students' entrepreneurial intention. Journal of Small Business Management, 53(4), 1127-1145.

Solesvik, M. Z., Westhead, P., Kolvereid, L., \& Matlay, H. (2012). Student intentions to become self-employed: the Ukrainian context. Journal of Small Business and Enterprise Development, 19(3), 441-460.

Stephan, U., \& Uhlaner, L. M. (2010). Performance-based vs socially supportive culture: A cross-national study of descriptive norms and entrepreneurship. Journal of International Business $\quad$ Studies, $11(8), \quad 1347-1364$. https://doi.org/10.1057/jibs.2010.14

Suraya, F. R., Firdaus, M., Uzair, H., Khairi, M., \& Amirul Zharif, Z. (2018). Prediction Of The Unemployment Rate In Malaysia. International Journal of Modern Trends in Social Sciences, 1(4), 34-44.

Wang, Y. S., Lin, S. J., Yeh, C. H., Li, C. R., \& Li, H. T. (2016). What drives students' cyber entrepreneurial intention: The moderating role of disciplinary difference. Thinking Skills and Creativity, 22, 22-35. doi: 10.1016/j.tsc.2016.08.003 